\title{
Current Status and Future Strategies to Treat Spinal Cord Injury with Adult Stem Cells
}

\author{
Seong Kyun Jeong, ${ }^{1}$ Il Choi, ${ }^{2}$ Sang Ryong Jeon' \\ Department of Neurological Surgery, Asan Medical Center, University of Ulsan College of Medicine, Seoul, Korea \\ Department of Neurological Surgery, ${ }^{2}$ Hallym University Dongtan Sacred Heart Hospital, Hwaseong, Korea
}

Spinal cord injury $(\mathrm{SCl})$ is one of the most devastating conditions and many $\mathrm{SCl}$ patients suffer neurological sequelae. Stem cell therapies are expected to be beneficial for many patients with central nervous system injuries, including SCl. Adult stem cells (ASCs) are not associated with the risks which embryonic stem cells have such as malignant transformation, or ethical problems, and can be obtained relatively easily. Consequently, many researchers are currently studying the effects of ASCs in clinical trials. The environment of transplanted cells applied in the injured spinal cord differs between the phases of SCl; therefore, many researchers have investigated these phases to determine the optimal time window for stem cell therapy in animals. In addition, the results of clinical trials should be evaluated according to the phase in which stem cells are transplanted. In general, the subacute phase is considered to be optimal for stem cell transplantation. Among various candidates of transplantable ASCs, mesenchymal stem cells (MSCs) are most widely studied due to their clinical safety. MSCs are also less immunogenic than neural stem/progenitor cells and consequently immunosuppressants are rarely required. Attempts have been made to enhance the effects of stem cells using scaffolds, trophic factors, cytokines, and other drugs in animal and/or human clinical studies. Over the past decade, several clinical trials have suggested that transplantation of MSCs into the injured spinal cord elicits therapeutic effects on SCl and is safe; however, the clinical effects are limited at present. Therefore, new therapeutic agents, such as genetically enhanced stem cells which effectively secrete neurotrophic factors or cytokines, must be developed based on the safety of pure MSCs.

Key Words : Adult stem cells - Spinal cord injuries · Mesenchymal stem cells · Neural stem cells · Genetic enhancement · Stem cell transplantation.

\section{INTRODUCTION}

Spinal cord injury (SCI) is one of the most devastating conditions in the neurosurgical field. Even with the best medical, surgical, and rehabilitative treatments, many SCI patients suffer neurological sequelae. Multiple strategies have been ap- plied to treat SCI patients, such as pharmacological treatment, neuromodulation, and surgical trials. Cell transplantation is considered to be a promising strategy due to the limited efficacies of other approaches. Among the many candidates for transplantable cells, embryonic stem cells (ESCs) have gained attention due to their capacities to differentiate into nearly all

- Received : June 23, 2019 •Revised : August 3, 2019 •Accepted : September 17, 2019

- Address for reprints : Sang Ryong Jeon

Department of Neurological Surgery, Asan Medical Center, University of Ulsan College of Medicine, 88 Olympic-ro 43-gil, Songpa-gu, Seoul 05505, Korea Tel : +82-2-3010-3550, Fax : +82-2-476-6738, E-mail : srjeon@amc.seoul.kr, ORCID : https://orcid.org/0000-0002-8340-7978

This is an Open Access article distributed under the terms of the Creative Commons Attribution Non-Commercial License (http://creativecommons.org/licenses/by-nc/4.0) which permits unrestricted non-commercial use, distribution, and reproduction in any medium, provided the original work is properly cited. 
human tissues and to undergo unlimited expansion in vitro, and thereby generate the required number of cells ${ }^{20)}$. However, although ESCs have advantages over adult stem cells (ASCs) in terms of their accessibility, expansion, and differentiation ${ }^{55}$, they carry the risk of tumorigenesis and are associated with ethical problems ${ }^{3,54)}$. Consequently, clinical interest in ASCs has grown. Here, we reviewed and summarized the current status of the development of ASCs therapies for SCI and described several future strategies to treat SCI using ASCs.

\section{STRATEGY OF STEM CELL THERAPY FOR SCI}

Spontaneous healing mechanisms, including remyelination, neural plasticity, and endogenous stem cell activation, are activated after SCI. However, these mechanisms are insufficient to produce clinically significant functional recovery in humans ${ }^{33)}$. The tissue targets in SCI are mainly neuronal axons not neuronal bodies, and the target space is much smaller than the brain. Cellular treatment in SCI has several goals : re- ducing cell death and damage due to the secondary injury in the immediate phase after SCI, promoting axonal regeneration and tissue repair in the late phase ${ }^{36)}$. Stem cells facilitate spinal cord repair in the chronic phase via various mechanisms, such as enhancing remyelination of residual axons, secreting neurotrophic factors/cytokines, producing bridging materials to fill cavities formed upon SCI, resolving intramedullary cavity margins composed of glial scars ${ }^{37,41)}$, and activating endogenous intramedullary stem cells ${ }^{50)}$. Other mechanisms, which are promoting angiogenesis and reducing inflammation, may also be important in the acute phase of $\mathrm{SCI}^{36)}$.

Recently, an animal study was conducted based on the hypothesis that the central pattern generator (CPG) contributes to functional restoration in SCI upon stem cell therapy ${ }^{52}$. Within the spinal cord of mammals and other vertebrates, a neuronal circuit, called the CPG, is thought to generate repetitive motor patterns related to walking, running, and scratching. The CPG is known to be located in the L2 segment of the spinal cord in humans ${ }^{65)}$.

Table 1. Clinical trials of stem cell transplantation in the subacute phase of SCI

\begin{tabular}{|c|c|c|c|c|c|c|c|}
\hline Study & Stem cell type & Tx. time from SCI & $\mathrm{SCl}$ site & PreTx. AIS & $\mathrm{N}$ & PostTx. AIS & $\mathrm{N}$ \\
\hline \multirow[t]{4}{*}{ Shin et al. ${ }^{47)}(2015)$} & \multirow[t]{4}{*}{ NSPCS } & \multirow{4}{*}{$\begin{array}{c}63.4 \pm 54.1 \\
(18-213) \text { days }\end{array}$} & \multirow[t]{4}{*}{ Cervical } & \multirow[t]{3}{*}{ A } & \multirow[t]{3}{*}{17} & $A \rightarrow A$ & 14 \\
\hline & & & & & & $A \rightarrow B$ & 1 \\
\hline & & & & & & $A \rightarrow C$ & 2 \\
\hline & & & & B & 2 & $B \rightarrow D$ & 2 \\
\hline \multirow[t]{2}{*}{ Anderson et al. ${ }^{2)}$ (2017) } & \multirow[t]{2}{*}{$\mathrm{SCS}$} & \multirow{2}{*}{$\begin{array}{c}40.2 \pm 11.3 \\
(29-59) \text { days }\end{array}$} & \multirow[t]{2}{*}{ Thoracic } & \multirow[t]{2}{*}{ A } & \multirow[t]{2}{*}{6} & $A \rightarrow A$ & 5 \\
\hline & & & & & & $A \rightarrow B$ & 1 \\
\hline \multirow[t]{3}{*}{ Saito et al. ${ }^{45)}(2012)$} & \multirow[t]{3}{*}{ BM-MSCs } & \multirow{3}{*}{$\begin{array}{c}13.0 \pm 2.9 \\
(8-17) \text { days }\end{array}$} & \multirow[t]{3}{*}{ Cervical } & A & 3 & $A \rightarrow A$ & 3 \\
\hline & & & & B & 1 & $B \rightarrow D$ & 1 \\
\hline & & & & C & 1 & $C \rightarrow D$ & 1 \\
\hline \multirow[t]{2}{*}{ Karamouzian et al. ${ }^{23)}$ (2012) } & \multirow[t]{2}{*}{ BM-MNCs } & \multirow{2}{*}{$\begin{array}{c}27.3 \pm 8.4 \\
(14-43) \text { days }\end{array}$} & \multirow[t]{2}{*}{ Thoracic } & \multirow[t]{2}{*}{ A } & \multirow[t]{2}{*}{11} & $A \rightarrow A$ & 6 \\
\hline & & & & & & $A \rightarrow C$ & 5 \\
\hline \multirow[t]{4}{*}{ Park et al. ${ }^{40)}(2005)$} & \multirow[t]{4}{*}{$\mathrm{BM}-\mathrm{MCP}+\mathrm{GM}-\mathrm{CSF}$} & \multirow{3}{*}{$\begin{array}{c}9.8 \pm 2.9 \\
(7-14) \text { days }\end{array}$} & \multirow[t]{3}{*}{ Cervical } & \multirow[t]{3}{*}{ A } & \multirow[t]{3}{*}{4} & $A \rightarrow A$ & 1 \\
\hline & & & & & & $A \rightarrow B$ & 1 \\
\hline & & & & & & $A \rightarrow C$ & 2 \\
\hline & & 8 days & Thoracic & A & 1 & $A \rightarrow C$ & 1 \\
\hline \multirow[t]{3}{*}{ Knoller et al. ${ }^{27)}$ (2005) } & \multirow{3}{*}{$\begin{array}{l}\text { Activated autologous } \\
\text { macrophages }\end{array}$} & \multirow{3}{*}{$\begin{array}{c}12.3 \pm 1.9 \\
(9-14) \text { days }\end{array}$} & Cervical & A & 1 & $A \rightarrow C$ & 1 \\
\hline & & & Thoracic & A & 7 & $A \rightarrow A$ & 5 \\
\hline & & & & & & $A \rightarrow C$ & 2 \\
\hline
\end{tabular}

SCI : spinal cord injury, Tx. : treatment, AIS : American Spinal Injury Association Impairment Scale, N : number of patients, NSPC : neural stem/progenitor cell, SC : Schwann cell, BM : bone marrow, MSC : mesenchymal stem cell, MNC : mononuclear cell, MCP : mononuclear cell preparation, GM-CSF : granulocyte-macrophage colony-stimulating factor 


\section{TIME WINDOWS FOR STEM CELL THERAPY IN SCI}

According to the guidelines issued by the International Campaign for Cures of SCI Paralysis (ICCP) panel, the acute phase of SCI is defined as the period until the third day after injury, while the chronic phase is defined as the status after 12 months of injury with no neurological changes in the previous 6 months ${ }^{12}$. Consequently, the subacute phase has a broad time window. The environments of transplanted cells in the injured spinal cord differ according to the phases of SCI. Therefore, many researchers have investigated these phases to determine the optimal time window for stem cell therapy in animals $^{54)}$. In addition, the results of clinical trials should be evaluated according to the phase in which stem cells are transplanted to determine the optimal time window (Tables 1-3).

In animal studies, the subacute phase is generally considered to be optimal for stem cell transplantation ${ }^{36,54)}$. In this phase, glial scar formation is less advanced and the inflammatory response has subsided. Transplantation of stem cells in the subacute phase can prevent secondary injuries. In addition, transplanted stem cells survive better in the subacute phase than in the acute phase ${ }^{38}$. However, clinical trials of stem cell transplantation in the subacute phase require the enrollment of larger numbers of patients for case-control cohorts compared to the chronic phase which does not necessarily re-

Table 2. Clinical trials of stem cell transplantation in the chronic phase of SCl

\begin{tabular}{|c|c|c|c|c|c|c|c|}
\hline Study & Stem cell type & Tx. time from SCI & SCl site & PreTx. AIS & $\mathrm{N}$ & PostTx. AIS & $\mathrm{N}$ \\
\hline \multirow[t]{6}{*}{ Zhu et al. ${ }^{67)}$ (2016) } & \multirow[t]{6}{*}{ UCB-MNCS } & \multirow{6}{*}{$\begin{array}{c}8.8 \pm 6.2 \\
(1.6-20.0) \text { years }\end{array}$} & \multirow[t]{3}{*}{ Cervical } & \multirow[t]{2}{*}{$A$} & \multirow[t]{2}{*}{8} & $A \rightarrow A$ & 7 \\
\hline & & & & & & $A \rightarrow B$ & 1 \\
\hline & & & & C & 1 & $C \rightarrow C$ & 1 \\
\hline & & & \multirow[t]{3}{*}{ Thoracic } & \multirow[t]{3}{*}{ A } & \multirow[t]{3}{*}{19} & $A \rightarrow A$ & 14 \\
\hline & & & & & & $A \rightarrow B$ & 2 \\
\hline & & & & & & $A \rightarrow C$ & 3 \\
\hline \multirow[t]{3}{*}{ Vaquero et al..$^{59)}$ (2016) } & \multirow[t]{3}{*}{ BM-MSCs } & \multirow{3}{*}{$\begin{array}{c}13.9 \pm 9.4 \\
(3.2-26.8) \text { years }\end{array}$} & \multirow[t]{3}{*}{ Thoracic } & \multirow[t]{3}{*}{ A } & \multirow[t]{3}{*}{12} & $A \rightarrow A$ & 8 \\
\hline & & & & & & $A \rightarrow B$ & 3 \\
\hline & & & & & & $A \rightarrow C$ & 1 \\
\hline \multirow{2}{*}{ Oh et al. ${ }^{37)}$ (2016) } & \multirow[t]{2}{*}{ BM-MSCs } & \multirow{2}{*}{$\begin{array}{c}5.2 \pm 2.8 \\
(2.0-15.1) \text { years }\end{array}$} & \multirow[t]{2}{*}{ Cervical } & A & 1 & $A \rightarrow A$ & 1 \\
\hline & & & & B & 15 & $B \rightarrow B$ & 15 \\
\hline \multirow[t]{3}{*}{ Al-Zoubi et al.") (2014) } & \multirow{3}{*}{$\begin{array}{l}\text { Autologous, purified CD34+ } \\
\text { and CD133+ stem cells }\end{array}$} & \multirow[t]{3}{*}{$1.7 \pm 0.8(1.0-4.0)$ years } & \multirow[t]{3}{*}{ Thoracic } & \multirow[t]{3}{*}{ A } & \multirow[t]{3}{*}{19} & $A \rightarrow A$ & 10 \\
\hline & & & & & & $A \rightarrow B$ & 7 \\
\hline & & & & & & $A \rightarrow C$ & 2 \\
\hline \multirow[t]{3}{*}{ Mendonça et al..$^{34)}$ (2014) } & \multirow[t]{3}{*}{ BM-MSCs } & \multirow{3}{*}{$\begin{array}{c}5.1 \pm 4.1 \\
(1.5-15.0) \text { years }\end{array}$} & \multirow[t]{3}{*}{ Thoracic } & \multirow[t]{3}{*}{ A } & \multirow[t]{3}{*}{14} & $A \rightarrow A$ & 5 \\
\hline & & & & & & $A \rightarrow B$ & 6 \\
\hline & & & & & & $A \rightarrow C$ & 1 \\
\hline \multirow[t]{4}{*}{ Kishk et al. ${ }^{26)}$ (2010) } & BM-MSCs & $3.6 \pm 2.5$ years & Cervical, & A & 40 & $A \rightarrow A$ & 28 \\
\hline & & & thoracic & & & $A \rightarrow B$ & 11 \\
\hline & & & & & & $A \rightarrow C$ & 1 \\
\hline & & & Thoracic & C & 3 & $C \rightarrow C$ & 3 \\
\hline Deda et al. ${ }^{8)}$ (2008) & BM MCP & $\begin{array}{c}5.1 \pm 5.0 \\
(2-17) \text { years }\end{array}$ & $\begin{array}{l}\text { Cervical, } \\
\text { thoracic }\end{array}$ & $A$ & 9 & $A \rightarrow B$ & 2 \\
\hline Saberi et al. ${ }^{44)}(2008)$ & $\mathrm{SCS}$ & $3.9 \pm 1.7$ & Thoracic & A & 2 & $A \rightarrow A$ & 2 \\
\hline & & $(2.3-6.7)$ years & & C & 2 & $C \rightarrow C$ & 1 \\
\hline & & & & & & $C \rightarrow D$ & 1 \\
\hline
\end{tabular}

SCI : spinal cord injury, Tx. : treatment, AIS : American Spinal Injury Association Impairment Scale, N : number of patients, UCB : umbilical cord blood, MNC : mononuclear cell, BM : bone marrow, MSC : mesenchymal stem cell, MCP : mononuclear cell preparation, SC : Schwann cell 
Table 3. Clinical trials of stem cell transplantation in the mixed phase of SCI

\begin{tabular}{|c|c|c|c|c|c|c|c|}
\hline Study & Stem cell type & Tx. time from SCl & $\mathrm{SCl}$ site & PreTx. AIS & $\mathrm{N}$ & PostTx. AIS & $\mathrm{N}$ \\
\hline \multirow[t]{7}{*}{ Hur et al. ${ }^{19)}$ (2016) } & \multirow[t]{7}{*}{ AD-MSCs } & \multirow{4}{*}{$\begin{array}{c}17.4 \pm 6.2 \\
(12-28) \text { months }\end{array}$} & \multirow[t]{2}{*}{ Cervical } & $A$ & 2 & $A \rightarrow A$ & 2 \\
\hline & & & & $\mathrm{D}$ & 1 & $D \rightarrow D$ & 1 \\
\hline & & & Thoracic & A & 5 & $A \rightarrow A$ & 5 \\
\hline & & & Lumbar & $A$ & 1 & $A \rightarrow A$ & 1 \\
\hline & & \multirow{3}{*}{$\begin{array}{c}7.0 \pm 3.3 \\
\text { (3-11) months }\end{array}$} & Cervical & A & 3 & $A \rightarrow A$ & 3 \\
\hline & & & & B & 1 & $B \rightarrow B$ & 1 \\
\hline & & & Thoracic & $A$ & 1 & $A \rightarrow A$ & 1 \\
\hline \multirow[t]{5}{*}{ Bhanot et al. ${ }^{4)}$ (2011) } & \multirow[t]{5}{*}{ BM-MSCs } & \multirow{3}{*}{$\begin{array}{c}46.3 \pm 36.7 \\
(18-132) \text { months }\end{array}$} & Cervical & A & 4 & $A \rightarrow A$ & 4 \\
\hline & & & Thoracic & A & 7 & $A \rightarrow A$ & 6 \\
\hline & & & & & & $A \rightarrow B$ & 1 \\
\hline & & \multirow{2}{*}{$\begin{array}{c}6.8 \pm 2.7 \\
(3-10) \text { months }\end{array}$} & Cervical & A & 2 & $A \rightarrow A$ & 2 \\
\hline & & & Thoracic & A & 4 & $A \rightarrow A$ & 4 \\
\hline \multirow[t]{6}{*}{ Pal et al. ${ }^{39)}$ (2009) } & \multirow[t]{6}{*}{ BM-MSCs } & \multirow[t]{2}{*}{$>6$ months } & \multirow[t]{2}{*}{ Thoracic } & $A$ & 9 & $A \rightarrow A$ & 9 \\
\hline & & & & C & 1 & $C \rightarrow C$ & 1 \\
\hline & & \multirow[t]{4}{*}{$<6$ months } & \multirow[t]{2}{*}{ Cervical } & A & 6 & $A \rightarrow A$ & 2 \\
\hline & & & & C & 1 & $C \rightarrow C$ & 1 \\
\hline & & & \multirow[t]{2}{*}{ Thoracic } & A & 9 & $A \rightarrow A$ & 9 \\
\hline & & & & C & 4 & $C \rightarrow C$ & 3 \\
\hline \multirow[t]{6}{*}{ Geffner et al. ${ }^{14)}(2008)$} & \multirow[t]{6}{*}{ BM-MCP } & \multirow{4}{*}{$\begin{array}{c}10.2 \pm 6.7 \\
(5.8-21.8) \text { years }\end{array}$} & \multirow[t]{4}{*}{ Thoracic } & A & 1 & $A \rightarrow C$ & 1 \\
\hline & & & & B & 1 & $B \rightarrow C$ & 1 \\
\hline & & & & C & 2 & $C \rightarrow C$ & 1 \\
\hline & & & & & & $C \rightarrow D$ & 1 \\
\hline & & \multirow[t]{2}{*}{5 days to 7 months } & \multirow[t]{2}{*}{ Thoracic } & \multirow[t]{2}{*}{ A } & \multirow[t]{2}{*}{4} & $A \rightarrow A$ & 1 \\
\hline & & & & & & $A \rightarrow C$ & 3 \\
\hline Yoon et al. ${ }^{64)}$ (2007) & BM-MNCs & $<2$ weeks & Cervical, thoracic & A & 17 & $A \rightarrow A$ & 12 \\
\hline & & & & & & $A \rightarrow B$ or $A \rightarrow C$ & 5 \\
\hline & & 2-8 weeks & Cervical, thoracic & A & 6 & $A \rightarrow A$ & 4 \\
\hline & & & & & & $A \rightarrow B$ or $A \rightarrow C$ & 2 \\
\hline & & $>8$ weeks & Cervical, thoracic & $A$ & 12 & $A \rightarrow A$ & 12 \\
\hline Syková et al. ${ }^{511}$ (2006) & BM MCP & $18.0 \pm 2.9$ & Cervical & B & 1 & $B \rightarrow B$ & 1 \\
\hline & & (15-22) months & & C & 1 & $C \rightarrow C$ & 1 \\
\hline & & & Thoracic & A & 1 & $A \rightarrow A$ & 1 \\
\hline & & 10 days to 9 months & Cervical & A & 7 & $A \rightarrow A$ & 6 \\
\hline & & & & & & $A \rightarrow B$ & 1 \\
\hline & & & & B & 3 & $B \rightarrow B$ & 2 \\
\hline & & & & & & $B \rightarrow B$ & 1 \\
\hline & & & Thoracic & A & 7 & $A \rightarrow A$ & 7 \\
\hline Lima et al. ${ }^{29)}$ (2006) & OECs & $44.4 \pm 18.0$ & Cervical & A & 2 & $A \rightarrow A$ & 1 \\
\hline & & (30-78) months & & & & $A \rightarrow C$ & 1 \\
\hline & & & Thoracic & $A$ & 3 & $A \rightarrow A$ & 3 \\
\hline & & 6 months & Cervical & A & 1 & $A \rightarrow A$ & 1 \\
\hline & & & Thoracic & A & 1 & $A \rightarrow C$ & 1 \\
\hline
\end{tabular}

SCI : spinal cord injury, TX. : treatment, AIS : American Spinal Injury Association Impairment Scale, $\mathrm{N}$ : number of patients, AD : adipose tissue-derived, MSC : mesenchymal stem cell, BM : bone marrow, MCP : mononuclear cell preparation, MNC : mononuclear cell, OEC : olfactory ensheathing cell 
quire double-arm study ${ }^{37}$.

Tables 1-3 show the results of clinical trials using ASC transplantation (including one activated macrophage and two Schwann cell trials) in various phases of SCI according to the American Spinal Injury Association Impairment Scale (AIS). Although many SCI patients treated with ASCs showed no changes in terms of AIS, some studies reported improvements of two AIS grades $(A \rightarrow C \text { or } B \rightarrow D)^{1,14,23,26,27,34,40,45,47,51,59,64,67)}$. In addition, functional improvements such as walking ${ }^{1,14,23,39,40,45,67)}$ and bladder/bowel control ${ }^{1,14,19,26,27,34,39,45,59,67)}$ were used to reveal clinical change in several trials. It is challenging to directly compare the results of clinical trials between the subacute and chronic phases of SCI due to differences in the study design, population, and stem cell type. We could not determine whether stem cell transplantation in a certain phase leads to better clinical outcomes than in another phase based on the limited number of clinical trials presented in Table 3 .

\section{SAFETY OF ASCS}

When transplanting cells into the human spinal cord, the most important issues are safety and complications. Safety and complication issues can be evoked by delivering procedures, malignant potential, immunogenicity of transplanted cells, or medical condition of SCI patients. In most of the clinical trials presented in Tables 1-3, researchers reported that their clinical trials were safe without mortalities or severe morbidities related to either procedures or transplanted cells. However, there were some reported complications which were not associated with the procedures or applied cells : fever $^{4,40,59,64)}$, urinary tract infection ${ }^{2,19,27,59)}$, abnormal blood profiles $^{2,27,40,45)}$, transient hypertension ${ }^{26)}$, vomiting ${ }^{4,19)}$, pulmonary thromboembolism ${ }^{27}$, and general body ache ${ }^{4)}$. On the contrary, some complications including transient neuropathic pain $^{2,26,27,29,37,67)}$, transient deterioration in sensorimotor symptoms ${ }^{29,37,44,64)}$, cerebrospinal fluid leakage ${ }^{67)}$, subarachnoid hemorrhage ${ }^{67)}$ and subcutaneous seroma ${ }^{67}$, might be related to stem cell delivering procedures. Herein, we focused on the safety of stem cell themselves with respect to their malignant potential and immunogenic properties.

Olfactory ensheathing cells (OECs) or olfactory ensheathing glia (OEGs) are stem cells in the olfactory system. The OECs/ OEGs, the dominant glia in the peripheral nervous system, are known to guide axons along a defined path ${ }^{58}$. Given that OECs/OEGs can guide and ensheath axons, they are considered to be useful candidates for regeneration of the injured axon in spinal cord ${ }^{62}$. Although some studies reported that OECs/OEGs can be safely transplanted, the concerns about their safety still remain. In a human case report, intramedullary injected OECs/OEGs developed into a tumor when applied to treat chronic $\mathrm{SCI}^{11}$. Consequently, the safety of OECs/ OEGs is controversial.

Dental papillary stem cells or dental pulp stem cells (DPSCs) are another source of ASCs. These cells can be harvested relatively easily and readily from discarded human teeth, such as wisdom teeth. However, an animal study in which human DPSCs were injected into rat brains reported that all rats died within 2 weeks of transplantation due to malignant brain tumor formation ${ }^{63)}$. It is unclear whether DPSCs transformed into malignant tumor cells due to their inherent properties or due to the culture environment. No human clinical trial of DPSCs in SCI patients has been registered at ClinicalTrials. gov.

Transplanted Schwann cells (SCs) alter the inhibitory glial environment and induce axonal regeneration in $\mathrm{SCI}^{22}$. SCs are safe and there are no reports of malignant transformation or any other significant complications with these cells ${ }^{2}$. However, it is challenging to isolate SCs due to the risk of damaging other peripheral nerve segments, resulting in undesirable iatrogenic injury at the donor site ${ }^{60}$. New approaches to obtain SCs, such as differentiating these cells from bone marrow-derived mesenchymal stem cells (BM-MSCs) ${ }^{24}$, umbilical cordderived mesenchymal stem cells (UC-MSCs) ${ }^{32}$, and adipose tissue-derived mesenchymal stem cells (AD-MSCs) ${ }^{9)}$, were recently reported. These approaches may be safe options for cell therapy of SCI.

MSCs can be obtained from various sources, including bone marrow, umbilical cord, and adipose tissue, without ethical concerns ${ }^{25}$. MSCs are of the mesodermal lineage, but can transform into ectodermal and endodermal lineages ${ }^{57)}$. BM-MSCs are well studied and have relatively low immunogenicity $^{14)}$. In addition, these cells have never been reported to form malignant tumors in clinical trials ${ }^{28,57)}$. Thus, BM-MSCs have been studied as ideal candidates for stem cell therapy for a long time. UC-MSCs can be obtained from various sources, but are most commonly isolated from Wharton's jelly $y^{10}$. Animal studies suggested that UC-MSCs elicit anti-cancer effects 
on breast and lung cancer ${ }^{7)}$. AD-MSCs are more useful than BM-MSCs and UC-MSCs in terms of abundance and accessibility ${ }^{21)}$. However, there are fewer studies of AD-MSCs than of BM-MSCs and UC-MSCs.

Neural stem/progenitor cells (NSPCs) are multipotent cells that have self-renewing capacity and are destinated to differentiate into multiple neural lineages including neurons, oligodendrocytes, and astrocytes ${ }^{36)}$. NSPCs have capacity to replace lost tissues and provide trophic support at the injured sites and are expected to reconnect neuronal circuits in the injured spinal cords ${ }^{13)}$. Human NSPCs can be obtained from fetal or adult brain, and they can be also derived from ESCs and induced pluripotent stem cells. By developing alternative methods to obtain NSPCs, the ethical concerns by using human brain or ESC can be resolved, however, there is still the probability of tumorigenesis ${ }^{16)}$. The immunogenicity of NSPCs is still debated ${ }^{18,68)}$.

\section{COMPARISON OF MSCS AND NSPCS}

ASCs candidates for treating SCI can be divided into two groups : MSCs (such as BM-MSCs, UC-MSCs, and ADMSCs) and NSPCs. The major differences between these two groups of cells are the mechanisms by which they create therapeutic effects on SCI. In addition, their immunogenicity could be another different characteristic, which determines whether immunosuppressants are required or not.

MSCs do not usually differentiate into neural cells when injected into the spinal cord. However, many studies reported that transplantation of MSCs into the injured spinal cord exert functional improvement ${ }^{4,10,19,23,26,34,41,43)}$. Injected MSCs are thought to indirectly affect axonal regeneration. The suggested underlying mechanisms include activation of endogenous stem cells via the production of cytokines ${ }^{43)}$, removal of glial scars $^{41)}$, and formation of extracellular matrix which fills cavities and guides regenerating axons ${ }^{37)}$.

The rationale behind the use of NSPCs to treat SCI is based on replacement of destroyed tissue and provision of trophic support to surviving neuronal tissue ${ }^{36,52)}$. Indeed, neural stem cells secrete several neurotrophic factors such as nerve growth factor (NGF), brain-derived neurotrophic factor (BDNF), and glial cell-derived neurotrophic factor $(\mathrm{GDNF})^{30,49)}$. NPSCs are known to have less but no negligible immunogenic properties, and immunosuppression is believed to be essential for transplanted cell survival due to possibilities of low-grade rejection $^{56)}$. In a clinical trial that transplanted human NSPCs into subacute SCI patients, immunosuppression was performed from 3 days prior to transplantation until 9 weeks after transplantation ${ }^{47)}$. In a recent clinical study in which human NSPCs were transplanted into chronic cervical SCI patients, all subjects received immunosuppression regimens prior to engraftment and these were continued until 6 months post-transplantation to prevent graft rejection and mitigate any potential post-transplantation inflammatory responses ${ }^{15)}$.

Genetic modification of the MSCs may be a future tactic to improve therapeutic efficacy based on the safety of MSCs ${ }^{46)}$. Our previous studies ${ }^{37,41)}$ demonstrated that BM-MSCs can be safely transplanted and affect axonal regeneration, but their efficacy is insufficient. To overcome this drawback of pure MSCs, genetically enhanced MSCs must be developed.

\section{ARE ADDITIVE THERAPIES INCORPORATING STEM CELLS PROMISING?}

Animal and/or human clinical studies have sought to enhance the effects of stem cells using combined scaffolds, trophic factors $^{42)}$, cytokines ${ }^{35,64)}$, and other drugs ${ }^{67)}$.

Various animal studies investigated the effects of treatment with MSCs ${ }^{17,66)}$ and NSPCs ${ }^{5,53)}$ in combination with several scaffolds (poly lactic-co-glycolic acid, collagen, chitosan, gelatin, and hydroxypropyl methacrylate hydrogel with a ArgGly-Asp modification). These combination therapies improved axonal regeneration, stem cell differentiation, and functional improvement, and decreased scar formation ${ }^{6,31,48)}$. In a recent human clinical trial, combination treatment with a collagen scaffold and UC-MSCs in the acute phase of SCI improved the AIS grade from A to $\mathrm{C}$ in one patient with cervical SCI and one patient with thoracic SCI after 1 year of followup $^{61)}$.

Another method to enhance the effects of transplanted stem cells is to deliver them in combination with trophic factors. Animal studies in which stem cells (BM-MSCs, UCMSCs, OECs, NSPCs, and SCs) were administered in combination with trophic factors (NT3, BDNF, cyclic adenosine monophosphate, and fibroblast growth factor) could not conclusively clarify synergistic effects ${ }^{49)}$. In our previous study, we 
also did not observe any additive effects when AD-MSCs were administered in combination with granulocyte colony-stimulating factor in rats with acute $\mathrm{SCI}^{35}$.

In a clinical trial, treatment with autologous BM-MSCs in combination with granulocyte-macrophage colony-stimulating factor improved the AIS grade from A to B or from A to C in the acute and subacute phases of SCI, but did not induce any improvement in the chronic phase. However, this study did not include a control group using BM-MSCs only. In this regard, it is difficult to assess whether there was a synergistic effect $^{(6)}$. Another clinical trial of 28 SCI patients reported that combination treatment with UC-MSCs and lithium improved the AIS grade from A to C in three patients and from A to B in two patients; however, this study also did not include a control group using UC-MSCs only, and failed to show the synergistic effect of combined therapy ${ }^{67}$. Lithium stimulates secretion of NGF, NT3, and GDNF by UC-MSCs.

\section{CONCLUSIONS}

The strategy for stem cell application on SCI is distinct from other central nervous system pathologies and there are different characteristics in mechanisms of action and immunogenicity among ASCs. Over the past decade, several clinical trials have suggested that transplantation of MSCs into the injured spinal cord elicits therapeutic effects and is safe. However, the clinical efficacy remains limited. Therefore, new therapeutic stem cell agents, such as genetically enhanced stem cells that effectively secrete neurotrophic factors or cytokines, must be developed based on the safety of pure MSCs.

\section{CONFLICTS OF INTEREST}

No potential conflict of interest relevant to this article was reported.

\section{INFORMED CONSENT}

This type of study does not require informed consent.

\section{AUTHOR CONTRIBUTIONS}

\author{
Conceptualization : SRJ \\ Data curation : SKJ, IC \\ Formal analysis : SKJ \\ Funding acquisition : SRJ \\ Methodology : SRJ \\ Project administration : SRJ \\ Visualization : SKJ \\ Writing - original draft : SKJ, SRJ \\ Writing - review \& editing : SKJ, SRJ
}

\section{ORCID}

Seong Kyun Jeong https://orcid.org/0000-0001-9775-3882 Il Choi https://orcid.org/0000-0003-0120-6564 Sang Ryong Jeon https://orcid.org/0000-0002-8340-7978

\section{- Acknowledgements}

This research was supported by a grant from the Korea Health Technology R\&D Project through the Korea Health Industry Development Institute (KHIDI), funded by the Ministry of Health \& Welfare, Republic of Korea (grant number: HI16C2188). This study was supported by a grant (18-176, 19-

176) from the Asan Institute for Life Sciences, Seoul, Korea.

\section{References}

1. Al-Zoubi A, Jafar E, Jamous $M$, Al-Twal F, Al-Bakheet $S$, Zalloum M, et al. : Transplantation of purified autologous leukapheresis-derived CD34+ and CD133+ stem cells for patients with chronic spinal cord injuries: long-term evaluation of safety and efficacy. Cell Transplant 23 Suppl 1 : S25-S34, 2014

2. Anderson KD, Guest JD, Dietrich WD, Bartlett Bunge M, Curiel R, Dididze $M$, et al. : Safety of autologous human schwann cell transplantation in subacute thoracic spinal cord injury. J Neurotrauma 34 : 29502963, 2017

3. Arnhold S, Klein H, Semkova I, Addicks K, Schraermeyer U : Neurally selected embryonic stem cells induce tumor formation after long-term survival following engraftment into the subretinal space. Invest Ophthalmol Vis Sci $45:$ 4251-4255, 2004

4. Bhanot $Y$, Rao S, Ghosh D, Balaraju S, Radhika CR, Satish Kumar KV : Autologous mesenchymal stem cells in chronic spinal cord injury. Br J 
Neurosurg 25 : 516-522, 2011

5. Bozkurt G, Mothe AJ, Zahir T, Kim H, Shoichet MS, Tator CH : Chitosan channels containing spinal cord-derived stem/progenitor cells for repair of subacute spinal cord injury in the rat. Neurosurgery 67 : 17331744,2010

6. Chen BK, Madigan NN, Hakim JS, Dadsetan M, McMahon SS, Yaszemski MJ, et al. : GDNF Schwann cells in hydrogel scaffolds promote regional axon regeneration, remyelination and functional improvement after spinal cord transection in rats. J Tissue Eng Regen Med 12 : e398e407, 2018

7. Christodoulou I, Goulielmaki M, Devetzi M, Panagiotidis M, Koliakos G, Zoumpourlis V: Mesenchymal stem cells in preclinical cancer cytotherapy: a systematic review. Stem Cell Res Ther $9:$ 336, 2018

8. Deda H, Inci MC, Kürekçi $A E$, Kayihan K, Ozgün E, Ustünsoy GE, et al. : Treatment of chronic spinal cord injured patients with autologous bone marrow-derived hematopoietic stem cell transplantation: 1-year followup. Cytotherapy $10: 565-574,2008$

9. di Summa PG, Kingham PJ, Raffoul W, Wiberg M, Terenghi G, Kalbermatten DF : Adipose-derived stem cells enhance peripheral nerve regeneration. J Plast Reconstr Aesthet Surg 63 : 1544-1552, 2010

10. Ding DC, Chang YH, Shyu WC, Lin SZ: Human umbilical cord mesenchymal stem cells: a new era for stem cell therapy. Cell Transplant 24 : 339-347, 2015

11. Dlouhy BJ, Awe O, Rao RC, Kirby PA, Hitchon PW : Autograft-derived spinal cord mass following olfactory mucosal cell transplantation in a spinal cord injury patient: case report. J Neurosurg Spine 21 : 618622, 2014

12. Fawcett JW, Curt A, Steeves JD, Coleman WP, Tuszynski MH, Lammertse D, et al. : Guidelines for the conduct of clinical trials for spinal cord injury as developed by the ICCP panel: spontaneous recovery after spinal cord injury and statistical power needed for therapeutic clinical trials. Spinal Cord 45 : 190-205, 2007

13. Gage FH : Mammalian neural stem cells. Science 287 : 1433-1438, 2000

14. Geffner LF, Santacruz P, Izurieta M, Flor L, Maldonado B, Auad AH, et al. : Administration of autologous bone marrow stem cells into spinal cord injury patients via multiple routes is safe and improves their quality of life: comprehensive case studies. Cell Transplant 17 : 1277-1293, 2008

15. Ghobrial GM, Anderson KD, Dididze M, Martinez-Barrizonte J, Sunn GH, Gant KL, et al. : Human neural stem cell transplantation in chronic cervical spinal cord injury: functional outcomes at 12 months in a phase II clinical trial. Neurosurgery 64 (CN_suppl_1) : 87-91, 2017

16. González F, Boué S, Izpisúa Belmonte JC : Methods for making induced pluripotent stem cells: reprogramming à la carte. Nat Rev Genet 12 : 231-242, 2011

17. Hejcl A, Sedý J, Kapcalová M, Toro DA, Amemori T, Lesný $P$, et al. : HPMA-RGD hydrogels seeded with mesenchymal stem cells improve functional outcome in chronic spinal cord injury. Stem Cells Dev 19 : 1535-1546, 2010

18. Hori J, Ng TF, Shatos M, Klassen H, Streilein JW, Young MJ : Neural progenitor cells lack immunogenicity and resist destruction as allografts. Stem Cells $21:$ 405-416, 2003

19. Hur JW, Cho TH, Park DH, Lee JB, Park JY, Chung YG : Intrathecal transplantation of autologous adipose-derived mesenchymal stem cells for treating spinal cord injury: a human trial. J Spinal Cord Med 39 : 655 664, 2016

20. Hwang NS, Varghese S, Elisseeff J : Controlled differentiation of stem cells. Adv Drug Deliv Rev 60 : 199-214, 2008

21. Jeong JH, Lee JH, Jin ES, Min JK, Jeon SR, Choi KH : Regeneration of intervertebral discs in a rat disc degeneration model by implanted adipose-tissue-derived stromal cells. Acta Neurochir (Wien) 152 : 17711777,2010

22. Kanno $H$, Pearse DD, Ozawa $H$, Itoi E, Bunge MB : Schwann cell transplantation for spinal cord injury repair: its significant therapeutic potential and prospectus. Rev Neurosci 26 : 121-128, 2015

23. Karamouzian S, Nematollahi-Mahani SN, Nakhaee N, Eskandary H : Clinical safety and primary efficacy of bone marrow mesenchymal cell transplantation in subacute spinal cord injured patients. Clin Neurol Neuros 114 : 935-939, 2012

24. Keilhoff G, Goihl A, Langnäse K, Fansa H, Wolf $G$ : Transdifferentiation of mesenchymal stem cells into Schwann cell-like myelinating cells. Eur J Cell Biol 85 : 11-24, 2006

25. Kern S, Eichler $H$, Stoeve J, Klüter $H$, Bieback K : Comparative analysis of mesenchymal stem cells from bone marrow, umbilical cord blood, or adipose tissue. Stem Cells 24 : 1294-1301, 2006

26. Kishk NA, Gabr H, Hamdy S, Afifi L, Abokresha N, Mahmoud H, et al. : Case control series of intrathecal autologous bone marrow mesenchymal stem cell therapy for chronic spinal cord injury. Neurorehabil Neural Repair 24 : 702-708, 2010

27. Knoller N, Auerbach G, Fulga V, Zelig G, Attias J, Bakimer R, et al. : Clinical experience using incubated autologous macrophages as a treatment for complete spinal cord injury: phase I study results. J Neurosurg Spine 3 : 173-181, 2005

28. Lee HY, Hong IS : Double-edged sword of mesenchymal stem cells: cancer-promoting versus therapeutic potential. Cancer Sci 108 : 19391946, 2017

29. Lima C, Pratas-Vital J, Escada P, Hasse-Ferreira A, Capucho C, Peduzzi JD : Olfactory mucosa autografts in human spinal cord injury: a pilot clinical study. J Spinal Cord Med 29 : 191-203; discussion 204-246, 2006

30. Lu P, Jones LL, Snyder EY, Tuszynski MH : Neural stem cells constitutively secrete neurotrophic factors and promote extensive host axonal growth after spinal cord injury. Exp Neurol 181 : 115-129, 2003

31. Luo $L$, Albashari AA, Wang $X$, Jin L, Zhang $Y$, Zheng $L$, et al. : Effects of transplanted heparin-poloxamer hydrogel combining dental pulp stem cells and bFGF on spinal cord injury repair. Stem Cells Int 2018 : 2398521, 2018

32. Matsuse $D$, Kitada M, Kohama M, Nishikawa K, Makinoshima H, Wakao $\mathrm{S}$, et al. : Human umbilical cord-derived mesenchymal stromal cells differentiate into functional Schwann cells that sustain peripheral nerve regeneration. J Neuropathol Exp Neurol 69 : 973-985, 2010 
33. McDonough A, Martínez-Cerdeño V : Endogenous proliferation after spinal cord injury in animal models. Stem Cells Int 2012 : 387513, 2012

34. Mendonça MV, Larocca TF, de Freitas Souza BS, Villarreal CF, Silva LF, Matos AC, et al. : Safety and neurological assessments after autologous transplantation of bone marrow mesenchymal stem cells in subjects with chronic spinal cord injury. Stem Cell Res Ther 5 : 126, 2014

35. Min J, Kim JH, Choi KH, Yoon HH, Jeon SR : Is there additive therapeutic effect when GCSF combined with adipose-derived stem cell in a rat model of acute spinal cord injury? J Korean Neurosurg Soc 60 : 404416, 2017

36. Mothe AJ, Tator $\mathrm{CH}$ : Review of transplantation of neural stem/progenitor cells for spinal cord injury. Int J Dev Neurosci 31 : 701-713, 2013

37. Oh SK, Choi KH, Yoo JY, Kim DY, Kim SJ, Jeon SR : A phase III clinical trial showing limited efficacy of autologous mesenchymal stem cell therapy for spinal cord injury. Neurosurgery 78 : 436-447; discussion 447, 2016

38. Okada S, Ishii K, Yamane J, Iwanami A, Ikegami T, Katoh H, et al. : In vivo imaging of engrafted neural stem cells: its application in evaluating the optimal timing of transplantation for spinal cord injury. FASEB J 19 : 1839-1841, 2005

39. Pal R, Venkataramana NK, Bansal A, Balaraju S, Jan M, Chandra R, et al. : Ex vivo-expanded autologous bone marrow-derived mesenchymal stromal cells in human spinal cord injury/paraplegia: a pilot clinical study. Cytotherapy $11: 897-911,2009$

40. Park HC, Shim YS, Ha Y, Yoon SH, Park SR, Choi BH, et al. : Treatment of complete spinal cord injury patients by autologous bone marrow cell transplantation and administration of granulocyte-macrophage colony stimulating factor. Tissue Eng 11 : 913-922, 2005

41. Park JH, Kim DY, Sung IY, Choi GH, Jeon MH, Kim KK, et al. : Longterm results of spinal cord injury therapy using mesenchymal stem cells derived from bone marrow in humans. Neurosurgery 70 : 1238-1247; discussion 1247, 2012

42. Park JH, Min J, Baek SR, Kim SW, Kwon IK, Jeon SR : Enhanced neuroregenerative effects by scaffold for the treatment of a rat spinal cord injury with Wnt3a-secreting fibroblasts. Acta Neurochir (Wien) 155 : 809-816, 2013

43. Parr AM, Tator $\mathrm{CH}$, Keating $\mathrm{A}$ : Bone marrow-derived mesenchymal stromal cells for the repair of central nervous system injury. Bone Marrow Transplant $40: 609-619,2007$

44. Saberi H, Moshayedi P, Aghayan HR, Arjmand B, Hosseini SK, EmamiRazavi SH, et al. : Treatment of chronic thoracic spinal cord injury patients with autologous Schwann cell transplantation: an interim report on safety considerations and possible outcomes. Neurosci Lett 443 : 46-50, 2008

45. Saito F, Nakatani T, Iwase M, Maeda Y, Murao Y, Suzuki Y, et al. : Administration of cultured autologous bone marrow stromal cells into cerebrospinal fluid in spinal injury patients: a pilot study. Restor Neurol Neurosci 30 : 127-136, 2012

46. Seo DK, Kim JH, Min J, Yoon HH, Shin ES, Kim SW, et al. : Enhanced axonal regeneration by transplanted Wnt3a-secreting human mesenchymal stem cells in a rat model of spinal cord injury. Acta Neurochir (Wien) 159 : 947-957, 2017

47. Shin JC, Kim KN, Yoo J, Kim IS, Yun S, Lee H, et al. : Clinical trial of human fetal brain-derived neural stem/progenitor cell transplantation in patients with traumatic cervical spinal cord injury. Neural Plast 2015 : 630932, 2015

48. Shrestha B, Coykendall K, Li Y, Moon A, Priyadarshani P, Yao L : Repair of injured spinal cord using biomaterial scaffolds and stem cells. Stem Cell Res Ther 5 : 91, 2014

49. Silva NA, Sousa N, Reis RL, Salgado AJ : From basics to clinical: a comprehensive review on spinal cord injury. Prog Neurobiol 114 : 25-57, 2014

50. Stenudd M, Sabelström H, Frisén J : Role of endogenous neural stem cells in spinal cord injury and repair. JAMA Neurol 72 : 235-237, 2015

51. Syková E, Homola A, Mazanec R, Lachmann H, Konrádová SL, Kobylka $P$, et al. : Autologous bone marrow transplantation in patients with subacute and chronic spinal cord injury. Cell Transplant $15: 675-687$, 2006

52. Tashiro S, Nishimura S, Iwai $H$, Sugai $K$, Zhang L, Shinozaki $M$, et al. : Functional recovery from neural stem/progenitor cell transplantation combined with treadmill training in mice with chronic spinal cord injury. Sci Rep 6 : 30898, 2016

53. Teng YD, Lavik EB, Qu X, Park KI, Ourednik J, Zurakowski D, et al. : Functional recovery following traumatic spinal cord injury mediated by a unique polymer scaffold seeded with neural stem cells. Proc Natl Acad Sci U S A 99 : 3024-3029, 2002

54. Tetzlaff W, Okon EB, Karimi-Abdolrezaee S, Hill CE, Sparling JS, Plemel $J R$, et al. : A systematic review of cellular transplantation therapies for spinal cord injury. J Neurotrauma 28 : 1611-1682, 2011

55. Trounson A, McDonald $C$ : Stem cell therapies in clinical trials: progress and challenges. Cell Stem Cell $17: 11-22,2015$

56. Ubiali F, Nava S, Nessi V, Frigerio S, Parati E, Bernasconi P, et al. : Allorecognition of human neural stem cells by peripheral blood lymphocytes despite low expression of MHC molecules: role of TGF- $\beta$ in modulating proliferation. Int Immunol 19 : 1063-1074, 2007

57. Ullah I, Subbarao RB, Rho GJ : Human mesenchymal stem cells - current trends and future prospective. Biosci Rep 35 : e00191, 2015

58. Valverde F, Santacana M, Heredia M : Formation of an olfactory glomerulus: morphological aspects of development and organization. Neuroscience $49: 255-275,1992$

59. Vaquero J, Zurita M, Rico MA, Bonilla C, Aguayo C, Montilla J, et al. : An approach to personalized cell therapy in chronic complete paraplegia: The Puerta de Hierro phase I/II clinical trial. Cytotherapy 18 : 10251036, 2016

60. Wakao S, Matsuse D, Dezawa M : Mesenchymal stem cells as a source of Schwann cells: their anticipated use in peripheral nerve regeneration. Cells Tissues Organs $200: 31-41,2014$

61. Xiao Z, Tang F, Zhao Y, Han G, Yin N, Li X, et al. : Significant improvement of acute complete spinal cord injury patients diagnosed by a combined criteria implanted with neuroregen scaffolds and mesenchymal stem cells. Cell Transplant 27 : 907-915, 2018 
62. Yao R, Murtaza M, Velasquez JT, Todorovic M, Rayfield A, Ekberg J, et al. : Olfactory ensheathing cells for spinal cord injury: sniffing out the issues. Cell Transplant $27: 879-889,2018$

63. Yoon HH, Min J, Shin N, Kim YH, Kim JM, Hwang YS, et al. : Are human dental papilla-derived stem cell and human brain-derived neural stem cell transplantations suitable for treatment of Parkinson's disease? Neural Regen Res 8 : 1190-1200, 2013

64. Yoon SH, Shim YS, Park YH, Chung JK, Nam JH, Kim MO, et al. : Complete spinal cord injury treatment using autologous bone marrow cell transplantation and bone marrow stimulation with granulocyte macrophage-colony stimulating factor: phase I/II clinical trial. Stem Cells 25 : 2066-2073, 2007

65. Young $W$ : Electrical stimulation and motor recovery. Cell Transplant $24: 429-446,2015$
66. Zeng X, Zeng YS, Ma YH, Lu LY, Du BL, Zhang W, et al. : Bone marrow mesenchymal stem cells in a three-dimensional gelatin sponge scaffold attenuate inflammation, promote angiogenesis, and reduce cavity formation in experimental spinal cord injury. Cell Transplant 20 : 18811899, 2011

67. Zhu H, Poon W, Liu Y, Leung GK, Wong Y, Feng $Y$, et al. : Phase I-II clinical trial assessing safety and efficacy of umbilical cord blood mononuclear cell transplant therapy of chronic complete spinal cord injury. Cell Transplant 25 : 1925-1943, 2016

68. Ziv Y, Avidan H, Pluchino S, Martino G, Schwartz M : Synergy between immune cells and adult neural stem/progenitor cells promotes functional recovery from spinal cord injury. Proc Natl Acad Sci U S A 103 : 13174-13179, 2006 